\title{
Phytoremediation Potential of Freshwater Macrophytes for Treating Dye-Containing Wastewater
}

\author{
Karunakaran Gowri Ahila ${ }^{1}$, Balasubramani Ravindran ${ }^{2, *}$, Vasanthy Muthunarayanan ${ }^{3}$, Dinh Duc Nguyen ${ }^{2,4, *(\mathbb{D} \text {, }}$ \\ Xuan Cuong Nguyen ${ }^{5,6}$, Soon Woong Chang ${ }^{2}$, Van Khanh Nguyen $7, *$ (i) and Chandran Thamaraiselvi $1, * \mathbb{1}$
}

1 Department of Biotechnology, Mother Teresa Women's University, Kodaikanal, Tamil Nadu 624101, India; ahilabiotech2013@gmail.com

2 Department of Environmental Energy and Engineering, Kyonggi University Youngtong-Gu, Suwon 16227, Korea; swchang@kyonggi.ac.kr

3 Water and Solid Waste Processing Lab, Department of Environmental Biotechnology, Bharathidasan University, Tiruchirappalli, Tamil Nadu 620024, India; drvasanthy02@gmail.com

4 Faculty of Environmental and Food Engineering, Nguyen Tat Thanh University, 300A Nguyen Tat Thanh, District 4, Ho Chi Minh City 755414, Vietnam

5 Center for Advanced Chemistry, Institute of Research and Development, Duy Tan University, Da Nang 550000, Vietnam; nguyenxuancuong4@duytan.edu.vn

6 Faculty of Environmental Chemical Engineering, Duy Tan University, Da Nang 550000, Vietnam

7 Department of Microbiology, Pusan National University, Busan 46241, Korea

* Correspondence: kalamravi@gmail.com (B.R.); nguyensyduc@gmail.com (D.D.N.); khanhnv88@pusan.ac.kr (V.K.N.); thamaraibiotechnology@gmail.com (C.T.)

check for updates

Citation: Ahila, K.G.; Ravindran, B.; Muthunarayanan, V.; Nguyen, D.D.; Nguyen, X.C.; Chang, S.W.; Nguyen, V.K.; Thamaraiselvi, C.

Phytoremediation Potential of Freshwater Macrophytes for Treating Dye-Containing Wastewater. Sustainability 2021, 13, 329. https:// doi.org/10.3390/su13010329

Received: 3 November 2020 Accepted: 25 December 2020 Published: 31 December 2020

Publisher's Note: MDPI stays neutral with regard to jurisdictional clai$\mathrm{ms}$ in published maps and institutional affiliations.

Copyright: (C) 2020 by the authors. Licensee MDPI, Basel, Switzerland. This article is an open access article distributed under the terms and conditions of the Creative Commons Attribution (CC BY) license (https:// creativecommons.org/licenses/by/ $4.0 /)$.

\begin{abstract}
Phytoremediation is a promising green technology for the remediation of various industrial effluents. Notably, aquatic plants are widely applied to remove dyes and toxic metals from polluted environments. In the present study, the phytoremediation potency of aquatic macrophytes such as Pistia stratiotes L, Salvinia adnata Desv, and Hydrilla verticillata (L.f) Royle were assessed based on the removal capability of pollutants from dyeing effluent. Physicochemical characterizations were carried out for industrial wastewater collected from a cotton material dyeing unit located in the Karur District of Tamilnadu, India. The physicochemical characteristics of the dyeing effluent, such as color, odor, $\mathrm{pH}$, total dissolved solids (TDS), alkalinity, acidity, chloride, sulfate, phosphate, nitrate, chemical oxygen demand (COD), fluoride, and toxic metal levels were determined. The core parameters such as total dissolved solid (TDS), chemical oxygen demand (COD), and chloride level were determined and found to be $6500 \mathrm{mg} / \mathrm{L}, 2400 \mathrm{mg} / \mathrm{L}$, and $2050 \mathrm{mg} / \mathrm{L}$, respectively, which exceeded the regulatory limit prescribed by the Central Pollution Control Board of India. The levels of toxic metals such as $\mathrm{Hg}, \mathrm{Ni}$, and $\mathrm{Zn}$ were under the acceptable concentration but $\mathrm{Cr}$ and $\mathrm{Pb}$ levels in the dyeing effluent were a little bit higher. The effluent was subjected to treatment with Pistia stratiotes L, Salvinia adnata Desv and Hydrilla verticillata (L.f) Royle separately. After the treatment, the toxic metal results were recorded as below detectable levels and the same results were obtained for all three aquatic plants samples used for treatment. Among the three plants, P. stratiotes L efficiently removed $86 \%$ of color, $66 \%$ of TDS, $77 \%$ of COD, and $61.33 \%$ of chloride. The variation in phytochemicals of the macrophytes was studied before and after treatment using GC-MS which revealed the reduction of ascorbic acid in the plant samples. The toxic effect of treated effluent was investigated by irrigating an ornamental plant, Impatiens balsamina L. The plant biomass $P$. stratiotes $\mathrm{L}$ obtained after the treatment process was subjected to manure production and its nutrient quality was proved, which can be applied as a soil conditioner. Among the aquatic plants, the results of $P$. stratiotes $\mathrm{L}$ indicated a higher remediation potential, which can be used as an ecologically benign method for treatment of industrial effluents and water bodies contaminated with dyeing effluents.
\end{abstract}

Keywords: dye effluent; Pistia stratiotes L., phytoremediation; GC-MS; compost analysis 


\section{Introduction}

Water is considered as an important natural resource required for the growth and survival of all living organisms in the biosphere. The blooming of various industries, the human population explosion, and changes in climatic conditions and anthropogenic activities have led to the pollution and deterioration of the environment [1-3]. Textile industries are contributing to the enhancement of the economy in developed and developing countries [4]. In addition to this, these industries have been implicated as a producer of environmental pollution by utilizing and releasing a huge quantity of wastewater into the soil and into water bodies $[5,6]$. The wastewater of textile and bleaching industries is characterized by higher levels of toxic dye stuffs, chemical oxygen demand, total suspended solids, chloride, and carbonates [7].

The remediation of dye-containing wastewater is carried out by various physical and chemical techniques including reverse osmosis, filtration, adsorption, coagulation, electrocoagulation, flocculation, and oxidation. [8]. Most of these techniques are expensive, ineffective in the removal of certain pollutants, produce secondary pollution, and cause high sludge production $[9,10]$. Recently, effective biological approaches have been adopted for industrial effluent treatment along with methods to overcome the demerits of usual techniques.

Phytoremediation is an emerging, ecologically benign, reliable, inexpensive, aesthetically valued, and green approach that applies plants for the treatment of diverse industrial effluents as well as contaminated soil [11]. Naturally, plants are involved in some specific enzymatic pathways to degrade complex compounds to non-toxic compounds which reduce the pollution effect of contaminated areas [12]. Plants uptake the pollutants present in the contaminated environment through the root system and facilitate detoxification or degradation and/or accumulate pollutants via various plant mechanisms such as phytoextraction, rhizofiltration, phytostabilization, phytotransformation, rhizodegradation, and the phytovolatilization process $[1,13,14]$. Aquatic plants are widely used for the remediation of dyeing effluent due to their rapid growth, higher yield of plant biomass, and potency in the accumulation of nutrients and/or pollutants and toxic tolerant capability [15,16]. Eichhornia crassipes [17], Salvinia molesta [10], Salvinia cucullata [18], Lemna minor [19], Pistia stratiotes [15], and Chara vulgaris [6] are the water plants widely used for the treatment of wastewater.

The present study aimed to investigate the phytoremediation of dye-containing wastewater collected from the cotton dyeing industry using aquatic plants including Pistia stratiotes L, Salvinia adnata Desv, and Hydrilla verticillata (L.f) Royle. The reusability of the treated effluent and manure production from the obtained biomass was also evaluated. Methanolic extracts of aquatic plants were obtained and analyzed for their phytochemical content before and after treatments using gas chromatography-mass spectrometry (GC-MS).

\section{Materials and Methods}

\subsection{Wastewater Collection and Characterization}

The dyeing effluent sample was collected from the effluent treatment system of an ordinary cotton material dyeing industry located in the Karur district of Tamilnadu, India. The physicochemical parameters such as color, odor, $\mathrm{pH}$, total dissolved solids (TDS), alkalinity, acidity, chloride, sulfate, phosphate, nitrate, chemical oxygen demand (COD), and fluoride were determined according to the standard protocol of APHA (American Public Health Association) [20]. Toxic metals such as mercury, lead, zinc, nickel, and chromium were analyzed by atomic absorption spectroscopy (Perkin-Elmer model 3110, Waltham, MA, USA).

\subsection{Collection and Authentication of Aquatic Plants}

Pistia stratiotes L (family: Araceae; common name: water lettuce), Salvinia adnata Desv (family: Salviniaceae; common name: water fern), and Hydrilla verticillata (L.f) Royle (family: Hydrocharitaceae; common name: water thyme) (Figure 1) were collected from freshwater 
without the influence of dyeing effluent. The collected plants were authenticated by the botanical survey of India, Southern Regional Centre (TNAU campus, Lawley Road, Coimbatore, Tamilnadu, India) (Ref. No.: BSI/SRC/5/23/2017/Tech.2837).

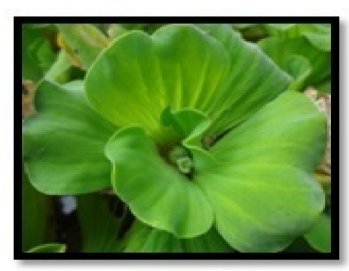

Pistia stratiotes $\mathbf{L}$

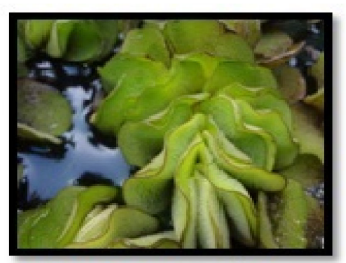

Salvinia adnata Desv

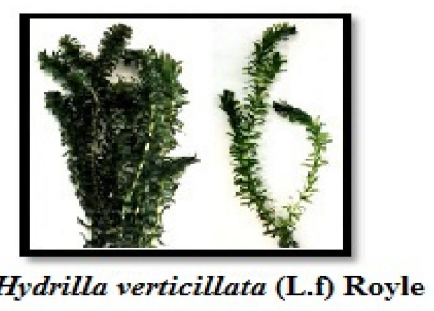

Hydrilla verticillata (L.f) Royle

Figure 1. Aquatic macrophytes were used in this study.

\subsection{Experimental Setup for Phytoremediation}

For the phytoremediation process, the plants were washed thoroughly with tap water and distilled water to remove dirt. The acclimatization was done in laboratory conditions with tap water only for 20 days. The alkaline nature of the effluent leads to the death of macrophytes. Hence, the $\mathrm{pH}$ was neutralized to 7.2 using acetic acid (1\%) for further treatment processing. After the neutralization of $\mathrm{pH}$, the aquatic macrophytes such as $P$. stratiotes L, S. adnata Desv, and H. verticillata (L.f) Royle were grown for evaluation of pollutant removal potential. Approximately $250 \mathrm{~g}$ of each plant was introduced into glass tanks containing $5 \mathrm{~L}$ of dyeing wastewater, separately. The effluent without plant was maintained as a control. The reduction of core parameters such as TDS, COD, and chloride were analyzed for treated effluent [20]. The toxic metals such as $\mathrm{Pb}$ and $\mathrm{Cr}$ were analyzed by AAS (Atomic Absorption Spectroscopy) after digestion of plant materials by the acid method using nitric acid and hydrogen peroxide digestion. In order to stabilize the tissue and to stop the enzymatic reactions, the plant samples were washed in deionized water, dried at $80^{\circ} \mathrm{C}$ for $24 \mathrm{~h}$, and then powdered. Later they were digested with nitric acid followed by hydrogen peroxide in a repeated heating process [21]. The methanolic extracts of all three varieties of aquatic plants were prepared using Soxhlet apparatus and phytochemical constituents were analyzed by gas chromatography-mass spectroscopy (GC-MS System; Agilent Technologies, CA, USA). The phytoconstituents were identified using NIST and Wiley databases. The decolorization efficacy of aquatic plants was determined by a UV-visible spectrophotometer (Elico Serial No. 218) based on the intensity of color at the wavelength of $540 \mathrm{~nm}$ observed before and after the phytoremediation process. All experiments were carried out in triplicate.

\subsection{Reusability of Phytoremediated Effluent}

The reusability of treated effluent was assessed by growing an ornamental plant named Impatiens balsamina L (family: Balsaminaceae). The experiments were conducted in Kodaikanal during the months of July-September under uniform conditions of light intensity, photoperiod, and temperature. An equal amount of soil was placed in three containers. All containers were maintained in an open air environment. Two sets of experiments were conducted. The healthy seeds of the Impatiens balsamina $\mathrm{L}$ were procured from a local market. The seeds were surface sterilized with $0.1 \% \mathrm{HgCl}_{2}$ and allowed to grow in three sets of containers. The first set was maintained as control which was irrigated with clean (tap) water every day. The second one was irrigated with $P$. stratiotes L-treated dyeing effluent regularly (DI, daily irrigation). The third set was alternatively flooded with tap water and P. stratiotes L-treated effluent (ADI, alternative day irrigation/first day irrigated with tap water second day irrigated with treated effluent, third day tap water, and likewise). The irrigation was done every morning at $8.30 \mathrm{am}$. The mean length of root, shoot, leaf, and number of flowers of 65-day-old plants were determined. An ANOVA calculation was done for the growth parameters of the control plant, ADI, and DI. The 
difference between the control plant and treated effluent irrigated plants was confirmed using an ANOVA test (IBM SPSS Version 20 package).

\subsection{Manure Production Using Plant Biomass}

The plant biomass obtained after the phytoremediation process was utilized for manure production. In total, four compost sets were carried out with different proportions of plant biomass with cow dung, agriculture waste, and filter papers used for filtration purposes. Pistia stratiotes L plant after phytoremediation was subjected to composting process with two different combinations including Set A (cow dung and P. stratiotes L biomass and agricultural waste in the ratio 1:2:1), Set B (cow dung, Pistia stratiotes L biomass and used filter papers 1:1:1), Set C (only cow dung), and Control (only Pistia stratiotes L biomass). These sets were allowed to undergo aerobic digestion and their moisture levels were maintained by a frequent sprinkling of water during the process. Furthermore, thorough mixing of the contents was done regularly. The physicochemical characteristics such as color, odor, $\mathrm{pH}$, moisture content, organic carbon, nitrogen, phosphorous, potassium, iron, and copper content in decomposed matter of the compost sets were analyzed. The manure value of the processed compost was investigated using a standard procedure [22].

\section{Results and Discussion}

\subsection{Wastewater Characterization}

The physical and chemical characteristics of cotton dyeing wastewater are given in Table 1. The color of the effluent was dark reddish due to the application of reactive red dyes for the dyeing process. The odor of wastewater was unpleasant. The TDS were determined to be $6500 \mathrm{mg} / \mathrm{L}$. The $\mathrm{pH}$ of the wastewater sample indicated quite high alkalinity ( $\mathrm{pH}$ 10.5). The disposal of highly concentrated dye-containing wastewater characterized with an elevated level of dissolved solids into the aquatic ecosystem prevents the penetration of sunlight which affects the photosynthetic process of aquatic vegetation as well as impeding the re-oxygenation potential of receiving water bodies [23]. The visible dye contaminants in the water resources reduce its aesthetic value and cause harmful effects such as allergy, cancer, and teratogenic effects in humans [24]. The total hardness, alkalinity, and COD of the wastewater were much higher than the regulatory level. Notably, the COD value is the typical factor for evaluating the quality of a water sample. Common anions in waters such as chloride, fluoride, phosphate, sulfate, and nitrate existed in the wastewater at a relatively high concentration. Nitrate and phosphate at a high level in wastewater can damage ecosystems by causing eutrophication [25]. Five representative toxic metals including $\mathrm{Hg}, \mathrm{Ni}, \mathrm{Zn}, \mathrm{Pb}$, and $\mathrm{Cr}$ were slightly higher than the standard limit recommended by the Central Pollution Control Board of India (CPCB). The other metals were below the standard limit and below the detectable level. [26].

\subsection{Phytoremediation Potency of Aquatic Plants}

The phytoremediation potency of three aquatic macrophytes is illustrated in Figures 2 and 3 , and the removal efficiency is summarized in Table 2. In the initial test, the aquatic plants wilted immediately due to the alkaline nature of the dye effluent, which was also explained previously. Therefore, the effluent was neutralized using $1 \%$ acetic acid which might also act as an enhancer for efficient treatment. After $48 \mathrm{~h}$ of incubating with aquatic plants, a color reduction in the wastewater was observed. However, the plants started to decay after the extension of treatment up to $72 \mathrm{~h}$ due to the uptake of contaminants and color (data not shown). 
Table 1. Physicochemical and heavy metal analysis of cotton dyeing effluent.

\begin{tabular}{ccc}
\hline Parameters & Results & Regulatory Level * \\
\hline Color & Dark red & Colorless \\
Odor & Unpleasant & Odorless \\
pH & 10.5 & $5.5-9.0$ \\
TDS & 6500 & 2100 \\
Total hardness & 280 & 100 \\
Alkalinity & 910 & 200 \\
Acidity & 230 & - \\
COD & 2400 & $250-400$ \\
Chloride & 2050 & $600-1000$ \\
Fluoride & 1.84 & 1.0 \\
Phosphate & 6.4 & - \\
Sulphate & 750 & 1000 \\
Nitrate & 90 & 45 \\
Lead & 0.014 & 0.01 \\
Mercury & BDL & 0.001 \\
Nickel & BDL & 0.02 \\
Zinc & 0.034 & 5 \\
Chromium & 0.078 & 0.05 \\
\hline
\end{tabular}

All the values are expressed as $\mathrm{mg} / \mathrm{L}$ except color, odor, and $\mathrm{pH}$. ${ }^{*}$ Acceptable level was regulated by the Central Pollution Control Board of India (CPCB). ${ }^{* *}$ BDL: below detectable level.

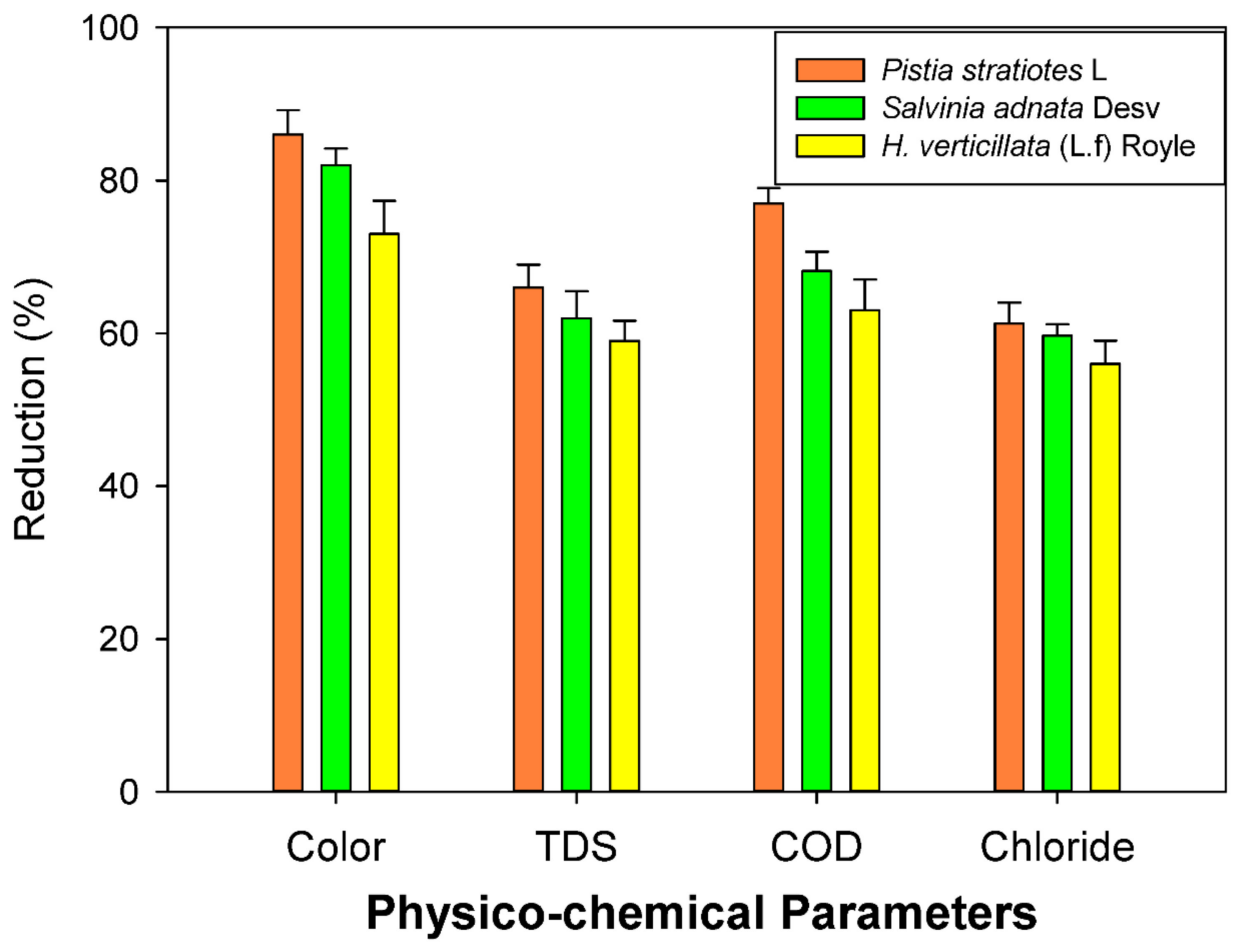

Figure 2. Removal percentage of pollutants from the effluent by aquatic macrophytes. 

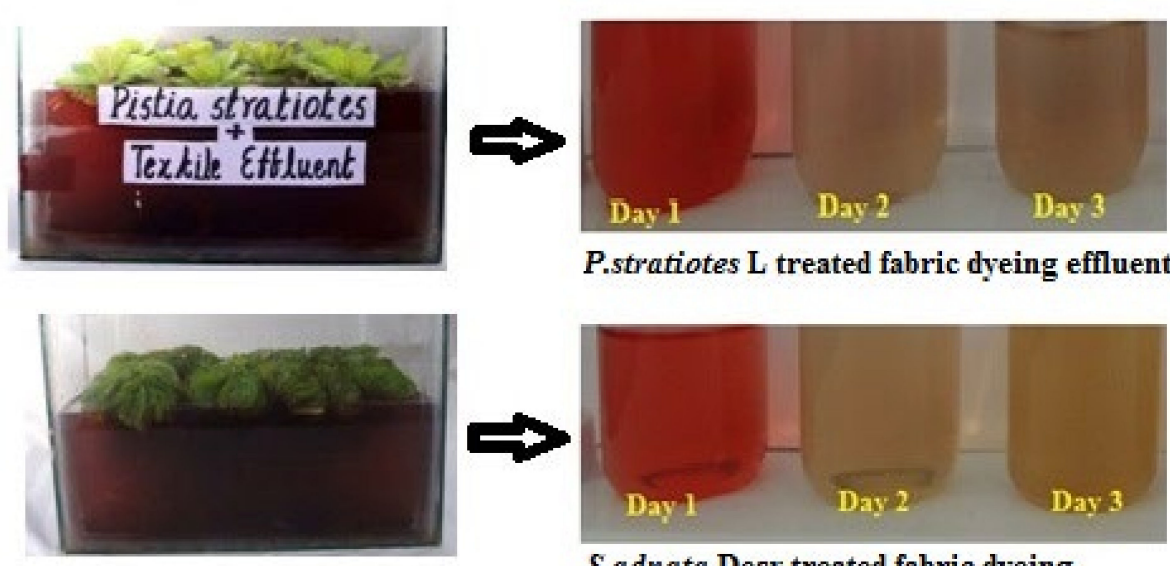

S.adnata Desv treated fabric dyeing effluent
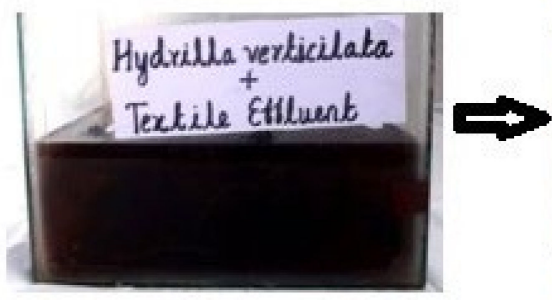

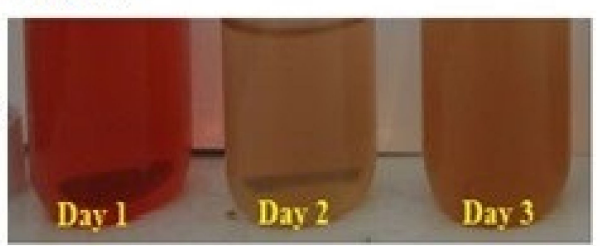

H.verticillata (L.f) Royle treated fabric dveing effluent

Figure 3. Decolorization of effluent by aquatic macrophytes.

Table 2. Effect of aquatic macrophytes on the removal of color, TDS (total dissolved solids), COD (chemical oxygen demand), and chloride from cotton dyeing effluent.

\begin{tabular}{|c|c|c|c|c|c|c|}
\hline \multirow[t]{2}{*}{ Aquatic Macrophytes } & \multicolumn{4}{|c|}{$\begin{array}{l}\text { Pollutants Reduction after Treatment (48 h) } \\
\text { (mg/L) }\end{array}$} & \multicolumn{2}{|c|}{$\begin{array}{l}\text { Heavy Metal in } \\
\text { Treated Effluent and } \\
\text { Used Plant Samples }\end{array}$} \\
\hline & Color * & TDS & COD & Chloride & $\mathrm{Pb}$ & $\mathrm{Cr}$ \\
\hline Control & Colorless & 6500 & 2400 & 2050 & 0.014 & 0.078 \\
\hline Pistia stratiotes $\mathrm{L}^{* *}$ & $86 \pm 3.202$ & 4290 & 1848 & 1250.5 & BDL & BDL \\
\hline Salvinia adnata Desv ** & $82 \pm 2.22$ & 4030 & 1632 & 1209.5 & BDL & BDL \\
\hline $\begin{array}{l}\text { H. verticillata (L.f) } \\
\text { Royle }^{* *}\end{array}$ & $73 \pm 4.36$ & 3835 & 1512 & 1148.5 & BDL & BDL \\
\hline
\end{tabular}

* Color expressed in \%. ${ }^{* *}$ The $\mathrm{Pb}$ and $\mathrm{Cr}$ levels of used plant samples were BDL.

The obtained results indicated that a removal efficiency higher than $50 \%$ was achieved for color, TDS, COD, and chloride after $48 \mathrm{~h}$ of treatment by the three plants. Among the three plants, Pistia stratiotes L showed the best performance for the removal of color, chloride, TDS, and COD, whereas H. verticillata (L.f) Royle exhibited the lowest removal efficiency (Figure 2). The TDS, COD and chloride level of Pistia stratiotes L-treated dyeing effluent were found to be $4290 \mathrm{mg} / \mathrm{L}, 1848 \mathrm{mg} / \mathrm{L}$, and $1250.5 \mathrm{mg} / \mathrm{L}$, respectively. The values of toxic metals, $\mathrm{Pb}$, and $\mathrm{Cr}$ of treated effluent and plant samples used for treatment were found to be below the detectable level (Table 2). Among the four environmental factors investigated during the phytoremediation, color was removed more efficiently than other factors such as TDS, COD, and chloride. A color removal efficiency of 73-86\% was achieved after $48 \mathrm{hr}$ of treatment by the three plants (Figure 3). Chloride seemed to be removed less than other parameters. Only 56-61.33\% of chloride was removed at the end of incubation of all plants. The $\mathrm{pH}$ of the effluent was neutralized before subjecting it to phytoremediation. After treatment, there was no significant change in $\mathrm{pH}$ observed. Similarly, the maximum decolorization potential of Eichhornia sp. in textile effluent was recorded by Anjana and Thanga [27]. P. stratiotes L was reported as an effective hyperaccumulator and could 
uptake the contaminants as well as nutrients through rhizofiltration mechanism and was utilized for growth, which resulted in a high biomass production [28]. In this study, the accumulation of dye stuffs was observed in the roots and leaves of $P$. stratiotes $L$ and $S$. adnata Desv plants (Figure 4). Anuradha et al. [29] stated that plant peroxidase is involved in the deterioration of textile dye substances. Ugya et al. [30] have reported the TDS- and TSS-reducing efficiency of $P$. stratiotes form textile wastewater. $\mathrm{Ng}$ et al. [31] achieved 39\% of COD and $95 \%$ of phosphate removal from palm oil mill effluent using Salvinia molesta. Likewise, Chandanshive et al. [10] reported the Rubine GFL dye decolourizing efficiency of Salvinia molesta D.C Mitch through the activation of oxidoreductase (azo-reductase, lacase, and catalase) and peroxidase enzymes. The phenolic compounds of plants were chiefly involved in the antioxidant activity during physiological stress that occurs in plants [32,33]. Xue and Yan [34] proved the arsenic-removal capability of $H$. verticillata (L.f) Royle through the phytoaccumulation and phytofiltration mechanism, by immobilizing arsenic in plant shoots. In the same pathway, P. stratiotes L might eliminate the pollutants from the dyeing effluent. Fonkou et al. [35] studied the efficiency of P. stratiotes $L$ to remove suspended solids, sulfates, phosphates, and turbidity from the wastewater. Al-Baldawi et al. [36] reported the methyl orange dye removal efficiency of Salvinia molesta and its FTIR test also confirmed the phytotransformation of methyl orange.

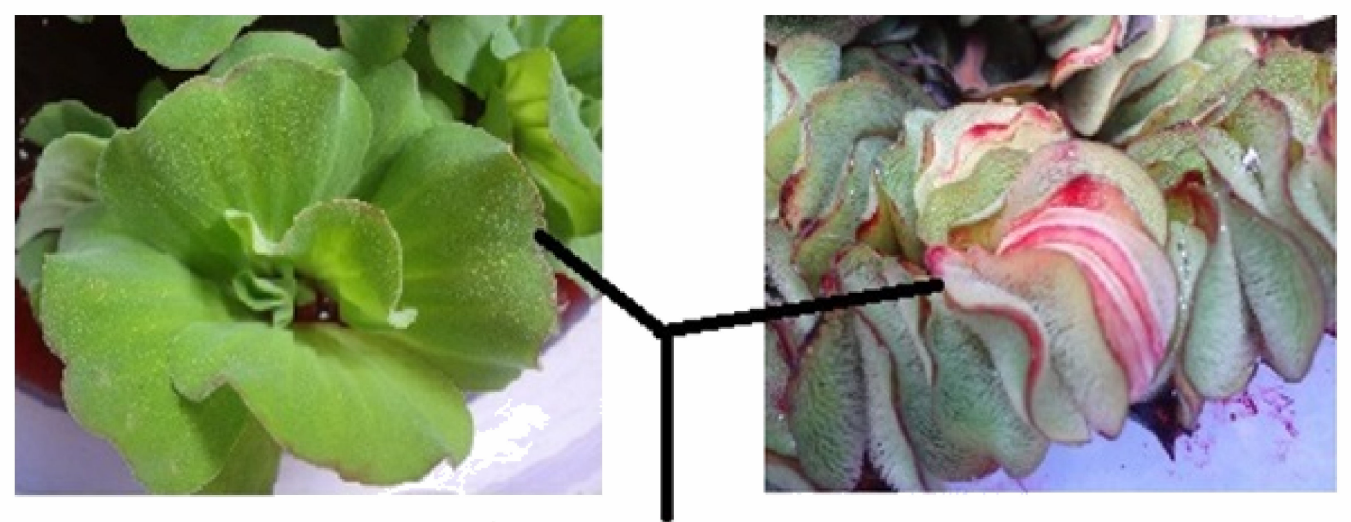

\section{Dye Accumulation by in P.Stratiotes L and S.adnata Desv}

Figure 4. Accumulation of dyes in P. stratiotes L and S. adnata Desv.

\subsection{GC-MS Analysis of Aquatic Plants before and after Phytoremediation}

The methanolic extract of total aquatic plants before and after testing was measured using GC-MS analysis and the GC-MS patterns showed various peaks corresponding to many phytocompounds. The methanolic extract of $P$. stratiotes $\mathrm{L}$ showed nine peaks indicating the presence of phytochemicals including 14-methyl-8-hexadecen-1-ol, pentadecanol, 9-eicosyne, oxirane, cyclodecanol, pentadecanoic acid, hexadecanoic acid, L-ascorbic acid, 11, 14, 17-eicostrienoic acid and stigmasterol (Figure 5a and Supplementary Table S1). The existence of hexadecanoic acid in the methanolic extract of Pistia stratiotes L and the antioxidant activity of this compound was noted by Tyagi and Agarwal [37]. The GC-MS pattern of treated Pistia stratiotes L showed the occurrence of hexadecyne, pentadecanol, cyclodecanol, hexadeconoic acid, tetradecanoic acid, and oleic acid (Figure 5b and Supplementary Table S2). After phytoremediation, the absence of L-ascorbic acid was observed in the extract of Pistia stratiotes L. It could be concluded that the antioxidant compounds might bind with contaminants and reduce the pollutants from the effluent. The phytochemical compounds in Salvinia adnata Desv extract were found to be pentadecanol, oleyl alcohol, L-ascorbic acid, tridecanoic acid, oleic acid, erucic acid, 1-naphthalene anthracene, and phenanthrene. The phytocompounds were determined based on the library search of observed peaks (Figure 5c and Supplementary Table S3). In the extract of Salvinia adnata Desv after phytoremediation, nonanolic acid, undecanoic acod, cyclopen- 
tane, tridecene, 4-n-butylthinane, 2-isopropyl, tetradecanoic acid, and stigmasterol-5 were observed (Figure $5 \mathrm{~d}$ and Supplementary Table S4).
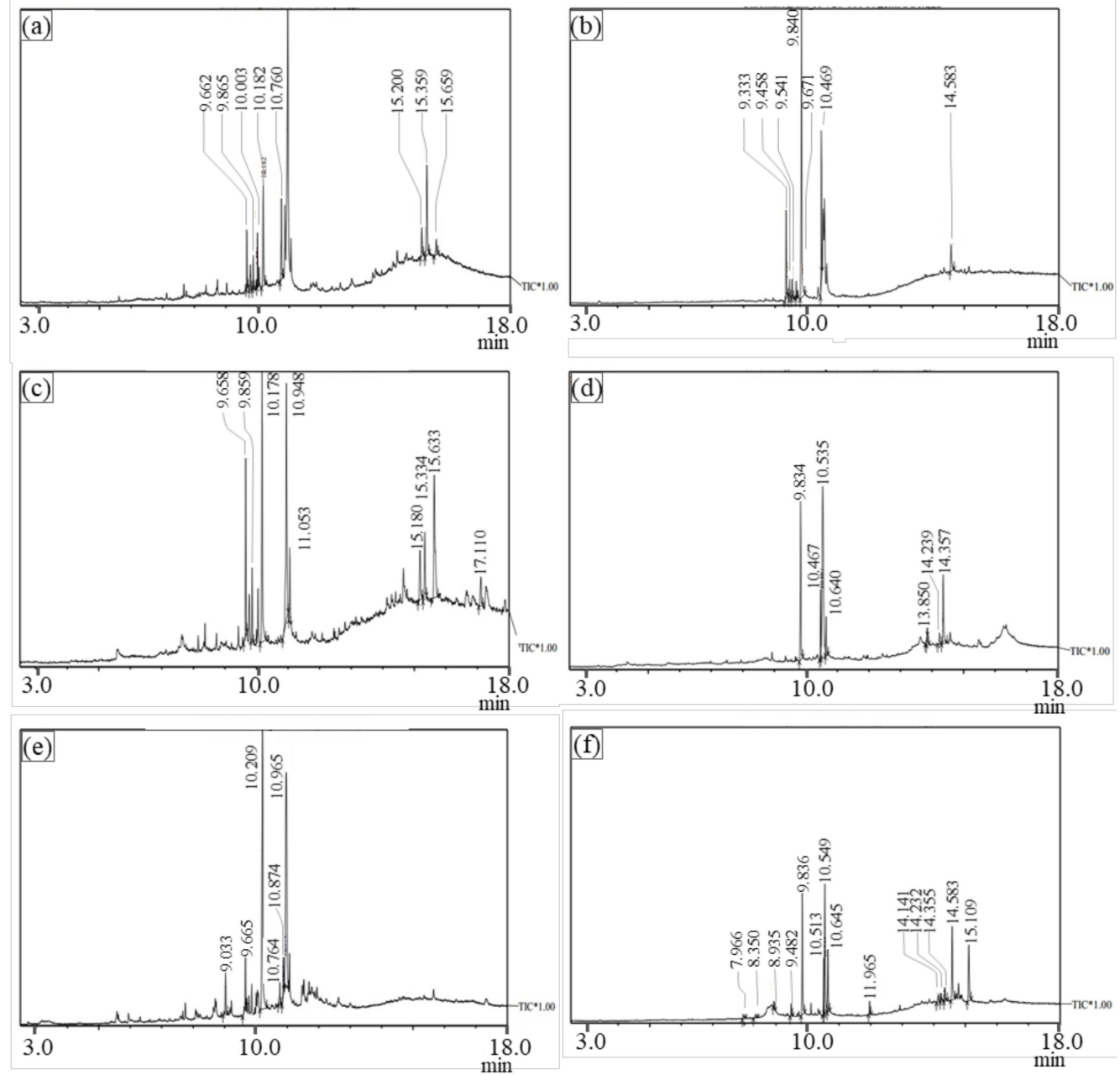

Figure 5. GC-MS chromatogram of Pistia stratiotes L (a,b), Salvinia adnata Desv (c,d) and Hydrilla verticillata (e,f) before and after phytoremediation.

The phytocompounds including 6-methyl-cyclodec-5-enol, 6-caranol, oxirane, oleyl alcohol, ascorbic acid, phytol-2-hexadecen, and 7-tetradecenal were found in the methanolic extract of Hydrilla verticillata (L.f) Royle (Figure 5e and Supplementary Table S5). In the extract of H.verticillata (L.f) Royle after phytoremediation, the disappearance of some peaks was observed. The detected phytocompounds in the extract of H. verticillata (L.f) Royle after phytoremediation include tetradecanoic acid, phytol, octadecatrienoic acid, oleic acid, and stigma sterol (Figure $5 \mathrm{f}$ and Supplementary Table S6). The decline in the level of some metabolites after treatment with plants might have contributed to improved tolerance in the plants. The alcoholic extracts of the three plants used for treatment showed the absence of ascorbic acid. Ascorbic acid can be deemed as a potential candidate for the removal of $\mathrm{Pb}$ and $\mathrm{Zn}$ from soil [38]. Ascorbic acid is a well-known antioxidant that might have been involved in the degradation of color molecules and substances found in dye effluent.

\subsection{Reusability of Phytoremediated Effluent}

The reusability of phytoremediated effluent was assessed by using it for irrigation purposes for the growth of the ornamental plant Impatiens balsamina L (balsam), because most of the partially treated dyeing industry effluents are directly utilized for agriculture purposes [39]. Because the maximum treatment efficiency was obtained by P.stratiotes $\mathrm{L}$, 
its treated effluent was utilized for a reusability study. The shoot length, root length, the number of flowers, leaf length, fresh weight, and dry weight were determined. The plant irrigated with phytoremediated effluent showed fine growth and the total length of the plant was found to be $107 \mathrm{~cm}$, leaf length was $10 \mathrm{~cm}$, and root length was $8-10 \mathrm{~cm}$. The number of flowers was found to be 15-20. The normal growth of Impatiens balsamina $\mathrm{L}$ proves the reduction of the toxic level of the dyeing effluent after the phytoremediation treatment (Table 3). Similarly, Shanmugam et al. [40] studied the effect of textile effluents phytoremediated with Bacopa monnieri plant on the seed germination, growth, shoot and root length of oilseeds and cereal plants. They also reported that the presence of antioxidative and oxidative enzymes in roots and leaves are involved in the degradation of dyes. The effect of treated textile effluent on the growth of plants such as P. mungo, V. mungo [41], wheat cultivar [42], peanut [43], and Sorghum vulgare [44] has also been investigated previously. The effect of treated dyeing effluent on the growth of the Impatiens balsamina L plant was statistically proved by ANOVA calculation and showed $0.05 \%$ significance; the null hypothesis was accepted, in that there was no significant difference between the control plant and the alternative day irrigated (ADI) balsam plant (Table 4). Thus, the present result concluded that a reduction in toxicity of fabric dyeing effluent using eco-friendly phytoremediation techniques is possible.

Table 3. Effect of treated effluent on the growth parameters of Impatiens balsamina L plant.

\begin{tabular}{cccc}
\hline Growth Parameters & Control & Daily Irrigation & Alternative Day Irrigation \\
\hline Height & $107 \pm 0.33^{\mathrm{a}}$ & $96 \pm 0.5^{\mathrm{a}}$ & $101 \pm 0.5^{\mathrm{a}}$ \\
Root length & $10 \pm 0.44^{\mathrm{b}}$ & $8 \pm 0.44^{\mathrm{b}}$ & $9 \pm 0.15^{\mathrm{b}}$ \\
Shoot length & $97 \pm 0.30^{\mathrm{c}}$ & $88 \pm 0.51^{\mathrm{c}}$ & $92 \pm 0.47^{\mathrm{c}}$ \\
Leaf length & $11 \pm 0.15^{\mathrm{d}}$ & $10 \pm 0.18^{\mathrm{d}}$ & $10 \pm 0.28^{\mathrm{d}}$ \\
Number of Flowers & $22^{\mathrm{e}}$ & $13^{\mathrm{e}}$ & $20^{\mathrm{e}}$ \\
\hline
\end{tabular}

Superscript letters indicate the statistical significance.

Table 4. Statistical analysis (ANOVA).

\begin{tabular}{|c|c|c|c|c|c|c|c|}
\hline & $\begin{array}{l}\text { Source of } \\
\text { Variance }\end{array}$ & $\begin{array}{l}\text { Sum of the } \\
\text { Squares }\end{array}$ & $\begin{array}{l}\text { Degrees of } \\
\text { Freedom }\end{array}$ & $\begin{array}{c}\text { Mean } \\
\text { Squares }\end{array}$ & F-Ratio & $\begin{array}{c}\text { Calculated } \\
p \text {-Value }\end{array}$ & $\begin{array}{c}\text { Level of } \\
\text { Significance }\end{array}$ \\
\hline \multirow{2}{*}{$\begin{array}{l}\text { Control and } \\
\text { Daily } \\
\text { irrigation }\end{array}$} & $\begin{array}{l}\text { Between } \\
\text { groups }\end{array}$ & 102.4 & 1 & 102.4 & \multirow[t]{2}{*}{9.84615} & \multirow[t]{2}{*}{0.03492} & \multirow[t]{2}{*}{$\begin{array}{c}p>0.05 \\
\text { Significant }\end{array}$} \\
\hline & $\begin{array}{l}\text { Within } \\
\text { groups }\end{array}$ & $17,409.2$ & 8 & 2176.15 & & & \\
\hline \multirow{2}{*}{$\begin{array}{l}\text { Control and } \\
\text { Alternative } \\
\text { Day } \\
\text { Irrigation }\end{array}$} & $\begin{array}{l}\text { Between } \\
\text { groups }\end{array}$ & 22.5 & 1 & 22.5 & \multirow[t]{2}{*}{8.18182} & \multirow[t]{2}{*}{0.045912} & \multirow[t]{2}{*}{$\begin{array}{c}\quad p>0.05 \\
\text { Significant }\end{array}$} \\
\hline & $\begin{array}{l}\text { Within } \\
\text { groups }\end{array}$ & $17,842.4$ & 8 & 2230.3 & & & \\
\hline
\end{tabular}

\subsection{Reuse of Plant Biomass for Manure Production}

Pistia stratiotes L plant after phytoremediation was subjected to composting process with two different combinations including Set A, Set B, Set C (only cow dung), and Control (only Pistia stratiotes L biomass). The compost nutrient quality of all sets is given in Table 5.

The $\mathrm{pH}$ of all composts is comparable, but the compost of only Pistia stratiotes $\mathrm{L}$ biomass is slightly lower than others. Nitrogen and potassium content in the compost of only Pistia stratiotes L biomass was much higher than other composts while its phosphorus content was much lower than others. The organic carbon content of the compost of only Pistia stratiotes L biomass was the highest whereas its moisture content was the lowest. Iron and copper were not detected in the compost of only Pistia stratiotes L biomass. The level 
of NPK (Nitrogen, phosphorus, potassium) indicated that the compost maturity of Set B was optimal.

Table 5. The manure value analysis of composts.

\begin{tabular}{ccccc}
\hline & Set A & Set B & Set C & Control \\
\hline Color & Brownish black & Brownish black & Brown & Brown \\
Odor & Earthy & Earthy & Earthy & - \\
pH & 8.64 & 8.42 & 8.41 & $0.97 \%$ \\
Nitrogen & $1.01 \%$ & $1.12 \%$ & $0.23 \%$ & $2.71 \%$ \\
Phosphorus & $0.23 \%$ & $0.23 \%$ & $0.58 \%$ & $0.03 \%$ \\
Potassium & $0.68 \%$ & $0.72 \%$ & $8.70 \%$ & $2.62 \%$ \\
Organic Carbon & $14.10 \%$ & $11.70 \%$ & $22.1 \%$ & $31.40 \%$ \\
Moisture content & $33.7 \%$ & $24.0 \%$ & $2230 \mathrm{ppm}$ & $9.80 \%$ \\
Iron & $3121 \mathrm{ppm}$ & $3335 \mathrm{ppm}$ & $21.0 \mathrm{ppm}$ & - \\
Copper & $23.5 \mathrm{ppm}$ & $23.5 \mathrm{ppm}$ & $8.6: 1$ & - \\
C/N & $14.5: 1$ & $10.4: 1$ & $11.6: 1$ \\
\hline
\end{tabular}

The carbon to nitrogen ratio of the compost was also another factor used to confirm the maturity of the composting process. The C:N ratio of Set A (cow dung and P. stratiotes $\mathrm{L}$ biomass and agricultural waste in the ratio 1:2:1) was the highest (14.5:1), followed by that of the control (only Pistia stratiotes L biomass). The lowest C:N ratio was observed in the composting of Set C (only cow dung). Vasanthy et al. [17] prepared manure using treated aquatic plants and analyzed total nitrogen, organic carbon, and total phosphorous content in their samples. The compost maturity was confirmed based on the $\mathrm{C}: \mathrm{N}$ ratio after the composting process. Decomposition of the plant material with cow dung to compost may occur through the activity of thermophilic microorganisms. During the decomposition process, the carbon content in the sample converted into $\mathrm{CO}_{2}$, and the nitrogen level was elevated when the protein-rich compounds cleaved the nitrogen-containing compounds to ammonia and other byproducts [45]. Shukla et al. [46] reported the preparation of compost using tannery effluent treated with aquatic plant Vallisneria spiralis L biomass.

\section{Conclusions}

The present study revealed the phytoremediation potential of Pistia stratiotes L, Salvinia adnata Desv, and Hydrilla verticillata (L.f) Royle. Among these three aquatic plants, $P$. stratiotes L effectively reduced contaminants from the dyeing effluent without any change of $\mathrm{pH}$. The GC-MS analysis confirmed the changes in the phytochemical content, especially for ascorbic acid in the aquatic plants before and after the phytoremediation process. The reusability and detoxification of the treated effluent were confirmed based on the growth of I. balsamina L plant. The biomass obtained after treatment was used for compost production. The composting of cow dung and P. stratiotes L biomass and agricultural waste in the ratio 1:2:1 showed a higher content of nutrients than the other three composting sets. This study suggested the phytoremediation potential of P.stratiotes L which served as a sustainable approach for dyeing wastewater treatment. The plant biomass and liquid produced after the treatment process were recycled and used for composting and ornamental plant irrigation, which indicated a promising process for zero-waste discharge from dyeing industries. The utilization of $P$. stratiotes $\mathrm{L}$ for the treatment of dyeing industry wastewater may help to grow more plants and commercialize the plant products for these purposes, and this could be an efficient alternative method for wastewater treatment. The concept of reusing treated industrial effluent is one of the vital points in modern industry. The reuse of industrial effluent for irrigation and for industrial purposes provides major benefits in conserving water resources and preventing water scarcity issues. 
Supplementary Materials: The following are available online at https:/ / www.mdpi.com/2071-1 050/13/1/329/s1, Table S1: GC-MS analysis of P. stratiotes L before treatment, Table S2: GC-MS analysis of $P$. stratiotes L after treatment, Table S3: GC-MS analysis of Salvinia adnata Desv before treatment, Table S4: GC-MS analysis of Salvinia adnata Desv after treatment, Table S5: GC-MS analysis of Hydrilla verticillata (L.f) Royle before treatment, Table S6: GC-MS analysis of Hydrilla verticillata (L.f) Royle after treatment.

Author Contributions: Conceptualization, K.G.A. and B.R.; methodology, B.R. and V.M.; validation, V.K.N., D.D.N. and S.W.C.; formal analysis, K.G.A.; investigation, X.C.N.; data curation, V.K.N.; writing-original draft preparation, K.G.A.; writing—review and editing, V.K.N., D.D.N., and C.T.; supervision, C.T. All authors have read and agreed to the published version of the manuscript.

Funding: The authors are grateful to DST-INSPIRE fellowship authorities, SERB, TNSCST-Tamil Nadu India and UGC, UGC-SAP, DST-PURSE, DST-FIST, MHRD-RUSA, India for providing fund to finish this research work.

Institutional Review Board Statement: Not applicable.

Informed Consent Statement: Not applicable.

Data Availability Statement: Data was obtained from third party and are available at URL that were specified in paper.

Conflicts of Interest: The authors declare no conflict of interest.

\section{References}

1. Ali, S.; Abbas, Z.; Rizwan, M.; Zaheer, I.E.; Yavaş, İ.; Ünay, A.; Abdel-DAIM, M.M.; Bin-Jumah, M.; Hasanuzzaman, M.; Kalderis, D. Application of Floating Aquatic Plants in Phytoremediation of Heavy Metals Polluted Water: A Review. Sustainability 2020, 12, 1927. [CrossRef]

2. Islam, M.A.; Ali, I.; Karim, S.M.A.; Hossain Firoz, M.S.; Chowdhury, A.N.; Morton, D.W.; Angove, M.J. Removal of dye from polluted water using novel nano manganese oxide-based materials. J. Water Process. Eng. 2019, 32, 100911. [CrossRef]

3. Kumwimba, M.N.; Zhu, B.; Suanon, F.; Muyembe, D.K.; Dzakpasu, M. Long-term impact of primary domestic sewage on metal/loid accumulation in drainage ditch sediments, plants and water: Implications for phytoremediation and restoration. Sci. Total Environ. 2017, 581-582, 773-781. [CrossRef] [PubMed]

4. Ahluwalia, S.S.; Goyal, D. Microbial and plant derived biomass for removal of heavy metals from wastewater. Bioresour. Technol. 2007, 98, 2243-2257. [CrossRef]

5. Tehrani-Bagha, A.R.; Mahmoodi, N.M.; Menger, F.M. Degradation of a persistent organic dye from colored textile wastewater by ozonation. Desalination 2010, 260, 34-38. [CrossRef]

6. Mahajan, P.; Kaushal, J.; Upmanyu, A.; Bhatti, J. Assessment of Phytoremediation Potential of Chara vulgaris to Treat Toxic Pollutants of Textile Effluent. J. Toxicol. 2019, 2019. [CrossRef]

7. Zaharia, C.; Suteu, C.; Muresan, A. Options and solutions of textile effluent Decolourization using some specific physicochemical treatment steps. In Proceedings of the 6th International Conference on Environmental Engineering and Management ICEEM' 06, Balaton Lake, Hungary, 1 September 2011; pp. 121-122.

8. Kabra, A.N.; Khandare, R.V.; Govindwar, S.P. Development of a bioreactor for remediation of textile effluent and dye mixture: A plant-bacterial synergistic strategy. Water Res. 2013, 47, 1035-1048. [CrossRef]

9. Tabinda, A.B.; Arif, R.A.; Yasar, A.; Baqir, M.; Rasheed, R.; Mahmood, A.; Iqbal, A. Treatment of textile effluents with Pistia stratiotes, Eichhornia crassipes and Oedogonium sp. Int. J. Phytoremediation 2019, 21, 939-943. [CrossRef]

10. Chandanshive, V.V.; Rane, N.R.; Gholave, A.R.; Patil, S.M.; Jeon, B.H.; Govindwar, S.P. Efficient decolorization and detoxification of textile industry effluent by Salvinia molesta in lagoon treatment. Environ. Res. 2016, 150, 88-96. [CrossRef]

11. Ekambaram, S.P.; Perumal, S.S.; Rajendran, D.; Samivel, D.; Khan, M.N. New approach of dye removal in textile effluent: A cost effective management for cleanup of toxic dyes in textile effluent by water hyacinth. In Toxicity and Biodegradation Testing; Bidoia, E., Montagnolli, R., Eds.; Humana Press: New York, NY, USA, 2018; pp. 241-267.

12. Govindwar, S.P.; Kagalkar, A.N. Phytoremediation Technologies for the Removal of Textile Dyes: An Overview and Future Prospectus; Nova Science Publisher: New York, NY, USA, 2010.

13. Ali, H.; Khan, E.; Sajad, M.A. Phytoremediation of heavy metals-Concepts and applications. Chemosphere 2013, 91, 869-881. [CrossRef]

14. Muthusamy, S.; Govindaraj, D.; Rajendran, K. Phytoremediation of textile dye effluents. In Bioremediation: Applications for Environmental Protection and Managements; Varjani, S., Agarwal, A.K., Gnansounou, E., Gurunathan, B., Eds.; Springer: Singapore, 2018; pp. 359-373.

15. Galal, T.M.; Eid, E.M.; Dakhil, M.A.; Hassan, L.M. Bioaccumulation and rhizofiltration potential of Pistia stratiotes L. for mitigating water pollution in the Egyptian wetlands. Int. J. Phytoremediation 2018, 20, 440-447. [CrossRef] [PubMed] 
16. Burges, A.; Alkorta, I.; Epelde, L.; Garbisu, C. From phytoremediation of soil contaminants to phytomanagement of ecosystem services in metal contaminated sites. Int. J. Phytoremediation 2018, 20, 384-397. [CrossRef] [PubMed]

17. Muthunarayanan, V.; Santhiya, M.; Swabna, V.; Geetha, A. Phytodegradation of textile dyes by Water Hyacinth (Eichhornia Crassipes) from aqueous dye solutions. Int. J. Environ. Sci. 2011, 1, 1702-1717.

18. Das, S.; Mazumdar, K. Phytoremediation potential of a novel fern, Salvinia cucullata, Roxb. Ex Bory, to pulp and paper mill effluent: Physiological and anatomical response. Chemosphere 2016, 163, 62-72. [CrossRef] [PubMed]

19. Shirinpur-Valadi, A.; Hatamzadeh, A.; Sedaghathoor, S. Study of the accumulation of contaminants by Cyperus alternifolius, Lemna minor, Eichhornia crassipes, and Canna $\times$ generalis in some contaminated aquatic environments. Environ. Sci. Pollut. Res. 2019, 26, 21340-21350. [CrossRef] [PubMed]

20. APHA Standard Methods for the Examination of Water and Wastewater 2012. Available online: https://www.standardmethods. org/ (accessed on 11 September 2018).

21. Jones, J.B.; Case, V.W. Sampling, Handling and Analyzing Plant Tissue Samples-Soil Testing and Plant Analysis; SSSA, Inc.: Madison, WI, USA, 1990.

22. AOAC Official Methods of Analysis, Association of Official Agricultural Chemists 2002. Available online: https://www.aoac. org/about-aoac-international/ (accessed on 28 September 2018).

23. Zaharia, C.; Suteu, D.; Muresan, A.; Muresan, R.; Popescu, A. Textile wastewater treatment by homogeneous oxidation with hydrogen peroxide. Environ. Eng. Manag. J. 2009, 8, 1359-1369. [CrossRef]

24. Victor, K.K.; Séka, Y.; Norbert, K.K.; Sanogo, T.A.; Celestin, A.B. Phytoremediation of wastewater toxicity using water hyacinth (Eichhornia crassipes) and water lettuce (Pistia stratiotes). Int. J. Phytoremediation 2016, 18, 949-955. [CrossRef]

25. Ngatia, L.; Grace, J.M., III; Moriasi, D.; Taylor, R. Nitrogen and Phosphorus Eutrophication in Marine Ecosystems. In Monitoring of Marine Pollution; IntechOpen: London, UK, 2019.

26. Sathiyaraj, G.; Chellappan Ravindran, K.; Hussain Malik, Z. Physico-chemical characteristics of textile effluent collected from Erode, Pallipalayam and Bhavani polluted regions, Tamilnadu, India. J. Ecobiotechnol. 2017, 9, 1-4. [CrossRef]

27. Anjana, S.; Thanga, V.S.G. Phytoremediation of synthetic textile dyes. Asian J. Microbiol. Biotechnol. Environ. Sci. 2011, 13, 31-34.

28. Thilakar, R.J.; Rathi, J.J.; Pillai, P.M. Phytoaccumulation of Chromium and Copper by Pistia stratiotes L. and Salvinia natans (L.) All. J. Nat. Prod. Plant Resour. 2012, 2, 725-730.

29. Kagalkar, A.N.; Jagtap, U.B.; Jadhav, J.P.; Bapat, V.A.; Govindwar, S.P. Biotechnological strategies for phytoremediation of the sulfonated azo dye Direct Red 5B using Blumea malcolmii Hook. Bioresour. Technol. 2009, 100, 4104-4110. [CrossRef] [PubMed]

30. Ugya, A.Y.; Hua, X.; Ma, J. Phytoremediation as a tool for the remediation of wastewater resulting from dyeing activities. Appl. Ecol. Environ. Res. 2019, 17, 3723-3735. [CrossRef]

31. Ng, Y.S.; Chan, D.J.C. Wastewater phytoremediation by Salvinia molesta. J. Water Process. Eng. 2017, 15, 107-115. [CrossRef]

32. Michalak, A. Phenolic compounds and their antioxidant activity in plants growing under heavy metal stress. Polish J. Environ. Stud. 2006, 15, 523-530.

33. Chantiratikul, P.; Meechai, P.; Woranan, N. Antioxidant activities and phenolic contents of extracts from salvinia molesta and Eichornia crassipes. Res. J. Biol. Sci. 2009, 4, 1113-1117.

34. Xue, P.Y.; Yan, C.Z. zhou Arsenic accumulation and translocation in the submerged macrophyte Hydrilla verticillata (L.f.) Royle. Chemosphere 2011, 85, 1176-1181. [CrossRef]

35. Fonkou, T.; Agendia, P.; Kengne, I.; Akoa, A.; Nya, J. Potentials of water lettuce (Pistia stratiotes) in domestic sewage treatment with macrophytic lahoon systems in Cameroo. In Proceedings of the International Symposium on Environmental Pollution Control and Waste Management, Tunis, Tunisia, 7-10 January 2002; pp. 709-714.

36. Al-Baldawi, I.A.; Abdullah, S.R.S.; Almansoory, A.F.; Hasan, H.A.; Anuar, N. Role of Salvinia molesta in biodecolorization of methyl orange dye from water. Sci. Rep. 2020, 10, 1-9. [CrossRef]

37. Tyagi, T.; Agarwal, M. Gas Chromatography-Mass Spectrometry analysis of bioactive constituents in the ethanolic extract of Pistia stratiotes L. Int. J. Basic Appl. Med. Sci. 2017, 7, 195-206.

38. Thinh, N.V.; Osanai, Y.; Adachi, T.; Vuong, B.T.S.; Kitano, I.; Chung, N.T.; Thai, P.K. Removal of lead and other toxic metals in heavily contaminated soil using biodegradable chelators: GLDA, citric acid andascorbic ascorbic acid. Chemosphere 2021, 263, 127912. [CrossRef]

39. Khandare, R.V.; Govindwar, S.P. Phytoremediation of textile dyes and effluents: Current scenario and future prospects. Biotechnol. Adv. 2015, 33, 1697-1714. [CrossRef]

40. Shanmugam, L.; Ahire, M.; Nikam, T. Bacopa monnieri (L.) Pennell, a potential plant species for degradation of textile azo dyes. Environ. Sci. Pollut. Res. 2020, 27, 9349-9363. [CrossRef] [PubMed]

41. Chandanshive, V.V.; Kadam, S.K.; Khandare, R.V.; Kurade, M.B.; Jeon, B.H.; Jadhav, J.P.; Govindwar, S.P. In situ phytoremediation of dyes from textile wastewater using garden ornamental plants, effect on soil quality and plant growth. Chemosphere 2018, 210, 968-976. [CrossRef] [PubMed]

42. Kaushik, P.; Garg, V.K.; Singh, B. Effect of textile effluents on growth performance of wheat cultivars. Bioresour. Technol. 2005, 96, 1189-1193. [CrossRef] [PubMed]

43. Saravanamoorthy, M.D.; Kumari, B.D.R.; Kumari, R. Effect of textile waste water on morphophysiology and yield on two varieties of peanut (Arachis hypogaea L.). J. Agric. Technol. 2007, 3, 335-343. 
44. Hayyat, M.U.; Mahmood, R.; Hassan, S.; Rizwan, S. Effects of textile effluent on growth performance of Sorghum vulgare Pers CV SSG-5000. Biologia 2013, 59, 15-22.

45. Li, G.; Zhang, F.; Sun, Y.; Wong, J.W.C.; Fang, M. Chemical evaluation of sewage sludge composting as a mature indicator for composting process. Water. Air. Soil Pollut. 2001, 132, 333-345. [CrossRef]

46. Shukla, O.P.; Rai, U.N.; Dubey, S. Involvement and interaction of microbial communities in the transformation and stabilization of chromium during the composting of tannery effluent treated biomass of Vallisneria spiralis L. Bioresour. Technol. 2009, 100, 2198-2203. [CrossRef] 